\title{
Defining the Scope of the Equal Protection Clause with Respect to Welfare Waiting Periods
}

\author{
Matthew Poppe $\dagger$
}

Since 1969, the Supreme Court has taken a generally dim view of lawis known as "durational residency requirements," which impose a waiting period before new state residents may enjoy certain rights or privileges granted to other state residents. ${ }^{1}$ In three cases, starting with Shapiro $v$ Thompson, ${ }^{2}$ the Court held that durational residency requirements "penalized" the "right to travel" and therefore warranted strict scrutiny review under the Equal Protection Clause of the Fourteenth Amendment. ${ }^{3}$ In each case, the Court invalidated the residency requirement after failing to find a "compelling state interest" capable of justifying the requirement."

Although, to some observers, these decisions marked the end of durational residency requirements affecting significant benefits, state legislatures have continued to invent ways to exclude new residents from the state's generosity. ${ }^{6}$ The benefits witheld since Shapiro have included eligibility for employment in career civil

† A.B. 1990, Stanford University; J.D. Candidate 1994, The University of Chicago.

1 Durational residency requirements should not be confused with ordinary residency requirements, which require residency for the receipt of benefits but impose no additional waiting period. Such requirements raise different constitutional issues. See, for example, Martinez v Bynum, 461 US 321, 325 (1983); Supreme Court of New Hampshire v Piper, 470 US 274 (1985).

2394 US 618 (1969), overruled on other grounds, Edelman v Jordan, 445 US 651, 671 (1974).

${ }^{3}$ Shapiro, 394 US at 638 (denial of welfare benefits); Dunn v Blumstein, 405 US 330 , 338-39 (1972) (voting privileges); Memorial Hospital $v$ Maricopa County, 415 US 250, 26162 (1974) (non-emergency medical care). See also Attorney General of New York $v$ SotoLopez, 476 US 898, 909 (1986) (prohibiting civil service employment preference for veterans who were New York residents upon entering military service).

4 Shapiro, 394 US at 618,642; Dunn, 405 US at 360; Memorial Hospital, 415 US at 269; Soto-Lopez, 476 US at 911.

- See, for example, Comment, The Demise of the Durational Residence Requirement, 26 Sw L J 538, 566-68 (1972); Note, Constitutional Law-Equal Protection and Residency Requirements, 49 NC L Rev 753, 762-63 (1971). This was obviously not a universal view. See, for example, Note, Shapiro v. Thompson: Travel, Welfare and the Constitution, 44 NYU L Rev 989, 1013 (1969).

- This Comment extends only to state durational residency requirements. The additional issues raised when Congress enacts such requirements will not be discussed. 
service positions, ${ }^{7}$ eligibility for shellfish licenses, ${ }^{8}$ and eligibility for employment by contractors on public works projects. ${ }^{9}$

More recently, several states have revived durational residency requirements for public assistance benefits similar to the waiting periods struck down by Shapiro. ${ }^{10}$ While superficially distinguishable from the Shapiro statutes, these new statutes conflict with the spirit of the Shapiro decision. Furthermore, they demonstrate political discontent with the constitutional restrictions imposed by the cases following Shapiro. Since many judges and commentators also object to the right to travel doctrine, ${ }^{11}$ the doctrine's continued viability is uncertain.

In light of this uncertainty, it is worthwhile to consider alternative constitutional approaches to welfare waiting periods. This Comment undertakes such an examination. Section I reviews the Supreme Court's modern right to travel cases, examines recent state efforts to revive welfare waiting periods in light of these precedents, and considers two alternative approaches to the right to travel that have been developed by individual members of the Supreme Court. Section II proposes an original approach that would treat indigent new residents as a "quasi-suspect class," and recommends that laws that disadvantage indigent newcomers should be subjected to intermediate equal protection scrutiny. Finally, Section III sketches the contours of a valid waiting period

7 Perez v Personnel Board of Chicago, 690 F Supp 670 (N D Ill 1988).

${ }^{8}$ Hassan $v$ East Hampton, 500 F Supp 1034 (E D NY 1980).

${ }^{\circ}$ Holland $v$ Bleigh Construction Co., 61 Ill 2d 258, 335 NE2d 469 (1975).

${ }^{10}$ See Cal Welf \& Inst Code $\S 11450.03$ (West Supp 1993), preliminary injunction enjoining implementation pending final disposition granted by Green $v$ Anderson, 811 F Supp 516, 523 (E D Cal 1993); 305 ILCS 5/11-30 (1992); Minn Stat Ann § 256D.065 (West Supp 1992), invalidated by Mitchell v Steffen, 487 NW2d 896 (Minn App 1992), aff'd, 504 NW2d 198 (Minn 1993); Wis Stat Ann $\S 49.015$ (West 1987 \& Supp 1992), upheld by Jones $v$ Milwaukee County, 168 Wis 2d 892, 485 NW2d 21, 22 (1992). New York has adopted a different home relief payment schedule for new residents. NY Soc Serv Law $\S 158$ (Law Coop 1993).

The California statute in particular demonstrates the popularity of welfare waiting periods. A proposal for a one-year waiting period originally appeared as one provision of a ballot initiative to be submitted to California voters in November, 1992. See Proposition 165, Cal Welf \& Inst Code $\$ 11450$ (c) (West Supp 1993) (noting the provision was to take effect if voters approved "Proposition 165" in 1992 election). The Democrat-controlled state legislature opposed Proposition 165 because it would also have effected more controversial changes in the welfare system and increased the budget-making powers of the (Republican) governor. See Vlae Kershner, State Limit on Newcomers' Welfare OKd, San Francisco Chron A24 (Nov 12, 1992). Fearing that the popularity of the waiting period would enable the initiative as a whole to succeed, the legislature passed its own waiting period, hoping to deflate support for the initiative. The scheme worked, sending Proposition 165 to a 54-46 percent defeat. Id.

${ }^{11}$ See notes 84-92 and accompanying text. 
under the proposed approach. It concludes that "employmentbased" waiting periods, which penalize only newcomers likely to remain on welfare indefinitely, should survive an attack based on the Equal Protection Clause.

\section{Modern Right to Travel Jurisprudence}

A. Penalizing the Right to Travel

When reviewing a statutory classification under the Equal Protection Clause of the Fourteenth Amendment, courts normally uphold the classification if it is rationally related to the furtherance of a legitimate governmental interest. ${ }^{12}$ This "rational basis" test reflects the deference that courts give to most legislative acts. Certain classifications, however, are subject to "strict scrutiny" and will survive only if they are shown to promote a "compelling state interest."13

Initially, the stricter standard applied only to classifications based on race, nationality, or alienage-all deemed to be "suspect" criteria. ${ }^{14}$ Subsequently, however, the Supreme Court hinted that strict scrutiny review would also apply to statutes that penalized the exercise of a "fundamental right" by a given class. ${ }^{15}$ Finally, in Shapiro $v$ Thompson, this "fundamental right" branch of strict scrutiny emerged as a fully developed component of equal protection doctrine. ${ }^{16}$

\section{Shapiro v Thompson.}

The Shapiro Court was faced with two state statutes and one District of Columbia statute that made AFDC benefits unavailable to new residents during their first year of residency. ${ }^{17}$ The statutes

${ }^{12}$ See United States Dept. of Agriculture v Moreno, 413 US 528, 533 (1973); Dandridge $v$ Williams, 397 US 471, 485 (1970).

${ }^{13}$ See City of Cleburne v Cleburne Living Center, Inc., 473 US 432, 440 (1985) (invalidating a zoning scheme requiring a special use permit for the operation of a group home for the mentally retarded). A middle tier of equal protection review, known as "intermediate scrutiny," exists as well. This standard is discussed in detail in the text accompanying notes 123-57.

14 See Graham v Richardson, 403 US 365, 371-72 (1971).

1s See Skinner v Oklahoma, 316 US 535, 541 (1942) (fundamental right to reproduce); Harper v Virginia Board of Elections, 383 US 663, 670 (1966) (fundamental right to vote).

${ }^{16} 394$ US at 634,638 .

17 Id at 621-22. "AFDC" stands for Aid to Families with Dependent Children. See generally 42 USC $\$ \S 601-617$ (1988 \& Supp 1991). Congress established the AFDC program in 1935 to provide financial assistance to needy children and their families. AFDC provides partial federal funding of state assistance plans that meet certain specifications. See 42 USC $\S 602$ (specifications), and $\S 603$ (payment to states). Although each state sets its own eligi- 
implicated the Equal Protection Clause because they created two classes of "needy resident families," distinguishable from each other only by length of residence, and since they denied. welfare benefits to one class solely on the basis of this distinction. ${ }^{18}$ The states attempted to justify the statutes in several ways. The Court found that the first asserted justification (discouraging an influx of poor families) was not a legitimate state interest ${ }^{19}$ and that the other justifications, though legitimate, were not sufficiently compelling to compensate for the detrimental effect on new residents' right to travel. ${ }^{20}$

The states first explained that the statutes were designed to reduce public assistance costs by discouraging an influx of poor families. ${ }^{21}$ The Court held this goal impermissible: the Constitution guarantees the right to travel from one state to another, and thus states may not "penalize" the exercise of that right." The residency requirements constituted penalties because they deprived recent migrants of "the very means to subsist-food, shelter, and other necessities of life." ${ }^{\text {"23 }}$ Even if the statutes had been tailored to deter only those indigents who moved into the states to obtain larger benefits, they would still have been unconstitutional. The Court did not "perceive why a mother . . . should be regarded

bility standards (subject to certain restrictions) and benefit levels, benefit levels generally are calculated as a function of a family's income and resources and the amount necessary for subsistence. See Paul E. Peterson and Mark C. Rom, Welfare Magnets 7 (Brookings Institution, 1990). Frequently, the parents of children receiving AFDC benefits must participate in work, training, or educational programs. See Joel F. Handler, The Transformation of Aid to Families with Dependent Children: The Family Support Act in Historical Context, 16 NYU Rev L \& Soc Change 457, 489-509, 513 (1987-88).

18 Shapiro, 394 US at 627.

18 Id at $631-32$.

20 Id at 638 .

${ }^{21}$ Id at 627-28. To this end, the welfare waiting periods apparently were effective. After Shapiro, interstate mobility increased dramatically. Peterson and Rom, Welfare Magnets at 17. This fact, however, does not necessarily support the "welfare magnet" theory, which posits that poor people will move interstate for the sole purpose of obtaining higher welfare benefits. It is quite possible that Shapiro merely made moving possible for individuals with valid reasons for doing so, but who could not afford to forego public assistance for one year.

${ }^{22}$ Shapiro, 394 US at 631-32. While the Shapiro Court cited no specific provision of the Constitution as the basis of the right to travel, the Court did note that earlier cases had pointed to the Commerce Clause, see Edwards v California, 314 US 160, 173 (1941), the Privileges and Immunities Clause of Art IV, § 2, see, for example, Paul $v$ Virginia, 75 US (8 Wall) 168,180 (1869), and the Privileges and Immunities Clause of the Fourteenth Amendment, see Twining $v$ New Jersey, 211 US 78, 97 (1908). Shapiro, 394 US at $630 \mathrm{n}$ 8. The Court has stated that the right to travel is more precisely referred to as the right of free interstate migration. Soto-Lopez, 476 US at 902.

${ }^{23}$ Shapiro, 394 US at 627. 
as less deserving because she considers, among other factors, the level of a State's public assistance."24

The states also tried to justify the statutes by alleging that they furthered several mostly administrative objectives: facilitating the planning of the welfare budget, providing an objective test of residency, minimizing the opportunity for recipients to receive payments fraudulently from more than one jurisdiction, and encouraging early entry of new residents into the labor force. ${ }^{28}$ While admitting that these objectives were permissible, the Court held that only a compelling governmental interest could save the statutes, again because the laws penalized the exercise of the right to travel. ${ }^{26}$ Unconvinced that the justifications advanced by the states were sufficiently compelling, the Court struck down the statutes. ${ }^{27}$

Shapiro made clear that a statute must survive strict scrutiny if it penalizes the exercise of the right to travel. But the Shapiro Court never defined what sort of restrictions on the right to travel would rise to the level of "penalties." While the Court found that a temporary deprivation of a "necessity of life" constituted such a penalty, it also stated that some durational residency requirements "may not be penalties upon the exercise of the constitutional right of interstate travel."28 In particular, the Court did not make clear whether a fundamental right could be "penalized" for equal protection purposes if the statute in question did not independently violate the implicated constitutional right.

\section{Shapiro's progeny.}

The Court next had occasion to examine a durational residency requirement in Dunn $v$ Blumstein. ${ }^{29}$ Tennessee had passed a law requiring one year of state residence and three months of residence in a particular county to vote in state elections. Blumstein, a Tennessee resident who had not satisfied the durational requirements, challenged the law after he was not permitted to register to vote. ${ }^{30}$

Examining the statute under the Equal Protection Clause, the Court found that the statute implicated two fundamental rights

\footnotetext{
24 Id at 632.

${ }^{23}$ Id at 634 .

26 Id.

27 Id at 642 .

${ }^{28}$ Id at $627,638 \mathrm{n} 21$.

29405 US 330 (1972).

so Id at 331-32.
} 
and applied strict scrutiny. ${ }^{31}$ First, the statute deprived some citizens of the right to vote, "a fundamental political right, . . . preservative of all rights." 32 And because the statute denied the vote only to recent immigrants, it penalized the right to travel. ${ }^{33} \mathrm{Re}-$ jecting two proposed justifications (protecting against fraud and ensuring that the voter is a "knowledgeable" member of the community), the Court struck down the statute. ${ }^{34}$

Again, the Court did not attempt to define "penalize." It can only be assumed that the right to vote was deemed a sufficiently important right that its temporary denial constituted a penalty. Dunn did clarify the term in one way, however, by noting that a statute need not actually deter travel to constitute a penalty against the right to travel. ${ }^{35}$

The Court unsheathed the right to travel doctrine again two years later in Memorial Hospital $v$ Maricopa County. ${ }^{36}$ At issue was an Arizona law making one year of residence in a particular county a condition of eligibility for non-emergency medical care at the county's expense. Memorial Hospital sought payment from Maricopa County for services given to a recent indigent migrant with respiratory problems. The county refused to pay, claiming it was barred from doing so by the statute. ${ }^{37}$

Like the other durational residency requirements, the Court reviewed the Arizona statute under the Equal Protection Clause. ${ }^{38}$ In order to determine which standard of review to apply, the Court again asked whether the statute penalized the right to interstate travel. ${ }^{39}$ It first found that the Arizona statute might deter sick

31 Id at 335 .

${ }^{32}$ Id at 336, quoting Reynolds $v$ Sims, 377 US 533, 562 (1964).

${ }^{33}$ Dunn, 405 US at 338-39. The Dunn Court stated in unqualified terms that "durational residence laws must be measured by a strict equal protection test." Id at 342 . Such language suggests that all durational residency requirements penalize the right to travel, but this clearly is not the case. See text accompanying note 28. See also Sosna $v$ Iowa, 419 US 393, 406-09 (1975) (upholding a one-year residency requirement before divorce proceedings can begin against a nonresident spouse).

${ }^{34}$ Dunn, 405 US at $345-60$.

35 Id at $339-40$.

${ }^{36} 415$ US 250 (1974).

${ }^{37}$ Id at 251-52.

38 Id at 253 .

${ }^{30}$ Id at 256. The Court rejected the argument that the statute penalized only intrastate travel, finding that its effect was to penalize interstate travel as well. Id at $255-56$. The Court therefore did not have to discuss whether intrastate travel was protected. One commentator has argued that the Constitution protects intrastate and interstate travel equally. See Comment, Toward a Constitutional Analysis of the Right to Intrastate Travel, $86 \mathrm{Nw}$ U L Rev 820 (1992). However, the Supreme Court recently dismissed a right to travel claim on standing grounds because the plaintiff had only moved across town, not from one state to 
indigents from migrating, which would automatically give rise to the compelling interest test. ${ }^{40}$ It then found that the statute penalized interstate travel because it deprived some new residents of medical care, which is "as much 'a basic necessity of life' to an indigent as [the] welfare assistance [at issue in Shapiro]." Court's view, "the right of interstate travel must be seen as insuring new residents the same right to vital government benefits and privileges in the States to which they migrate as are enjoyed by other residents." 42 The Court therefore applied strict scrutiny and, finding the statute's various rationales wanting, struck down the statute. ${ }^{43}$

Although the opinion did not claim to establish "the ultimate parameters of the Shapiro penalty analysis," 4 its use of the "necessity of life" concept is significant. The Court used this concept to distinguish earlier cases that upheld residency requirements for in-state tuition at state universities, stating that "we cannot equate [the] attainment [of higher education] with food, clothing and shelter."45 Furthermore, several lower courts have interpreted $\mathrm{Me}$ morial Hospital as establishing a minimum requirement that, before strict scrutiny applies, a durational residency requirement must affect a necessity of life. ${ }^{46}$

The Supreme Court has engaged in "penalty" analysis in only one other right to travel case, Attorney General of New York $v$ Soto-Lopez. ${ }^{47}$ In that case, a veteran challenged a provision of the New York Constitution that granted a civil service employment preference, in the form of points added to examination scores, to

another. Nordlinger $v$ Hahn, $112 \mathrm{~S}$ Ct 2326,2332 (1992) (state property tax scheme that imposed higher rates on more recent home buyers).

${ }^{40}$ Memorial Hospital, 415 US at 257-58.

41 Id at 259.

42 Id at 261. This view of the right to travel differs substantially from that expressed in Crandall $v$ Nevada, 73 US (6 Wall) 35 (1868), one of the first right to travel cases. Crandall saw the need for a right to travel mainly to guarantee Americans the ability to exercise their political rights at the seat of government. Id at 43-44. For a third view of the right to travel, see John Hart Ely, Democracy and Distrust 177-79 (Harvard, 1980) (casting the right to travel as an "exit option" to allow escape from an "incompatible majority").

13 Memorial Hospital, 415 US at 269-70.

4 Id at 259.

45 See id at 260 n 15, quoting Starns v Malkerson, 326 F Supp 234, 238 (D Minn 1970).

to See, for example, Hawaii Boating Ass'n v Water Trans. Facilities Div., 651 F2d 661, 665 (9th Cir 1981) (higher rates for mooring privileges at state small boat harbors were not a significant penalty, they were "merely uncomfortable"); Niles $v$ University Interscholastic League, 715 F2d 1027, 1030-31 (5th Cir 1983) (a rule restricting participation in interscholastic high school sports only incidentally affects the right to travel); Coolman $v$ Robinson, 452 F Supp 1324, 1328 (N D Ind 1978) (an alcoholic beverage license not a basic necessity).

476 US 898 (1986). 
certain veterans who resided in New York both when they took the test and when they entered military service. ${ }^{48}$ Soto-Lopez was denied the preference because, although a New York resident when he took a New York City civil service examination, he was a resident of Puerto Rico when he entered the Army. Hoping to get bonus points on his exam, he brought suit. ${ }^{49}$

A four-justice plurality employed essentially the same analysis as the Court had in Memorial Hospital. ${ }^{50}$ However, it relaxed the standard somewhat for applying strict scrutiny. Whereas Memorial Hospital indicated that a durational residency requirement had to deprive new residents of a "necessity of life" to merit strict scrutiny, the Soto-Lopez plurality concluded that the deprivation of any "very important" benefit or right would suffice. ${ }^{51}$ The plurality then found that while the employment preference "may not rise to the same level of importance as the necessities of life and the right to vote, it is unquestionably substantial."'52 Accordingly, the plurality applied strict scrutiny and invalidated the employment preference. ${ }^{53}$

Soto-Lopez was the first Supreme Court decision to indicate that a law may penalize newcomers even if the law gives newcom-

${ }^{18}$ Id at 900 (considering NY Const, Art V, § 6). This provision is not a durational residency requirement because it does not impose a waiting period before benefits can be received. Instead, more recent migrants are permanently barred from receiving preference points. Still, the provision is similar to a durational residency requirement in that it classifies based on length of residence.

A similar statute, granting Vietnam War veterans a $\$ 2,000$ property tax exemption if they had established residency in New Mexico prior to May 8, 1976, was overturned in Hooper v Bernalillo County Assessor, 472 US 612 (1985). There, the Court found no need to decide whether the statute penalized the right to interstate travel, holding that the statute failed to pass even the rational basis test. Id at 623 .

to Soto-Lopez, 476 US at 900-01.

so Id at 903-12. Two concurring justices found that the employment preference provision was invalid under the rational basis test. Justice White argued that the right to travel was not sufficiently compromised to require a compelling state interest, id at 916 (White concurring in the judgment), while Chief Justice Burger asserted that the Court could decide the case without reaching the right to travel question, id at 912-13 (Burger concurring in the judgment).

${ }^{81}$ Id at 907 (plurality opinion). The plurality used the terms "very important," "substantial," and "significant" interchangeably in describing the benefits the denial of which would invoke strict scrutiny. Id at 907-09.

62 Id at 988. Since Soto-Lopez, at least one lower court has overturned a statute that denied new residents a benefit that similarly could be classified as "substantial," but not "necessary" to life or health. See Perez v Personnel Board of Chicago, 690 F Supp 670, 677 (N D Ill 1988) (applying strict scrutiny to a statute that required applicants for career civil service positions to be Chicago residents at time of application). See also Hassan $v$ East Hampton, 500 F Supp 1034, 1041 (E D NY 1980) (applying strict scrutiny to a one-year waiting period to receive shellfish license).

s3 Soto-Lopez, 476 US at 911-12. 
ers a benefit unavailable in other states, so long as the law favors long-time residents. ${ }^{54}$ In one passage, the Soto-Lopez plurality discussed Zobel $v$ Williams, ${ }^{\text {,5 }}$ a case in which the Court held unconstitutional an Alaska dividend program that annually distributed a portion of the state's oil-reserves earnings in varying amounts based on the length of each citizen's residence. ${ }^{58}$ The Zobel Court invalidated the program under the rational basis test without reaching the question of whether the program penalized the exercise of the right to travel. ${ }^{.7}$ Nevertheless, the Soto-Lopez plurality stated that "the conclusion that [the contested law] did penalize migration may be inferred" from language in the Zobel opinion. ${ }^{58}$

Soto-Lopez is also important because it addressed a question left unresolved by Shapiro: whether a "penalty" on the right to travel in the equal protection context also constitutes an independent violation of the right to travel. Soto-Lopez provided an affirmative response, explaining that the standard of review applied to durational residency requirements is the same "regardless of the label we place on our analysis-right to migrate or equal protection . . . ."59 Thus, the Shapiro line of cases concluded by establishing the right of interstate travel as a distinct constitutional right that guarantees migrants access to substantial rights and benefits on an equal basis with more established residents.

\section{B. Application of the Shapiro Doctrine to Recent Welfare Wait- ing Periods}

Before the Supreme Court decided Shapiro, 46 states and the District of Columbia had laws that required new residents to wait a certain period of time before receiving welfare ${ }^{60}$ Shapiro seemingly put an end to this use of durational residency requirements to freeze the distribution of the welfare burden. However, recent state budget crises have led to the reemergence of welfare waiting

st See id at 908 .

s8 457 US 55 (1982).

so Id at 57,65. See also text accompanying notes 104-19.

${ }^{37}$ Zobel, 457 US at 60-61, 65.

ss Soto-Lopez, 476 US at 908, citing Zobel, 457 US at 59.

s9 Soto-Lopez, 476 US at $904 \mathrm{n}$ 4. This paraphrases Zobel, where the Court stated that "right to travel analysis refers to little more than a particular application of equal protection analysis." 457 US at $60 \mathrm{n} 6$.

${ }^{\circ 0}$ Shapiro, 394 US at 624 n 3 (majority opinion); id at 676 n 36 (Harlan dissenting). 
periods in several states as state officials have sought innovative ways to cut spending. ${ }^{61}$

The states have not challenged Shapiro directly. Rather, they have adopted statutes that, though clearly contrary to the spirit of Shapiro, are factually distinguishable from the statutes Shapiro struck down. This strategy has enjoyed mixed success.

\section{The Wisconsin approach: a shorter waiting period.}

In 1986, Wisconsin became the first state to enact a welfare waiting period since shortly after Shapiro. ${ }^{62}$ The Wisconsin legislature acted on a belief that Wisconsin's relatively high welfare levels ${ }^{63}$ were attracting poor families from states that offered less public assistance. ${ }^{64}$ The drafters employed two gimmicks to avoid Shapiro's prohibitions. First, they made the waiting period shorter: sixty days as opposed to one year. ${ }^{65}$ Second, they made newcomers with various ties to Wisconsin exempt from the loss of welfare eligibility. ${ }^{68}$ Thus, the statute arguably operated to deter only those migrants who came to Wisconsin for the sole purpose of collecting higher benefits.

The Wisconsin Supreme Court found these distinctions meaningful and upheld the waiting period in Jones $v$ Milwaukee County. ${ }^{67}$ The court first noted "[t]he unsettled nature of the degree to which a durational residency requirement must impinge upon the right to travel to be unconstitutional." that sixty days without welfare was "substantially less onerous"

${ }^{61}$ See, for example, Green v Anderson, 811 F Supp 516, 522 n 14 (E D Cal 1993); Kershner, State Limit on Newcomers' Welfare OKd at A24 (cited in note 10).

${ }^{62}$ See Wis Stat Ann $\S 49.015$.

es In 1985, Wisconsin law provided for an AFDC maximum monthly benefit of $\$ 533$ for a family of three. US House of Representatives, Committee on Ways and Means, 1990 Green Book 561-62 (GPO, 1990) ("Green Book"). At the time, this payment level was higher than the benefits offered by all neighboring states and topped the national median by 60 percent. See id. Wisconsin also made available "general relief" benefits funded entirely by the state. Peterson and Rom, Welfare Magnets at 28 (cited in note 17).

64 For an explanation and evaluation of this concern, see Thomas Corbett, The Wisconsin Welfare Magnet Debate, 13 Focus 19 (Fall/Winter 1991); Peterson and Rom, Welfare Magnets at 28-49.

es See Wis Stat Ann $\S 49.015(2)$.

${ }^{68}$ The statute exempted persons who were born in Wisconsin or had previously lived in Wisconsin for at least a year, who came to join a close relative or to accept an employment offer, or who came for a lawful purpose without intent to seek welfare benefits. Special provisions also permitted waivers in cases of medical emergency or unusual hardship. Wis Stat Ann § 49.015.

${ }^{87} 168$ Wis $2 \mathrm{~d} 892,485$ NW2d 21 (1992).

Id at 25, citing Memorial Hospital, 415 US 250. 
than a one-year deprivation, the court held that the Wisconsin statute did not penalize the right to travel. ${ }^{69}$ The court could still have found the residency requirement to be unconstitutional under the rational basis test by pointing out the legislature's specific (impermissible) purpose of deterring migration. Instead, the court focused on Wisconsin's "legitimate" interests in "preserving the public fisc" and "conserving scarce taxpayers' funds" in upholding the law. ${ }^{70}$

Although Jones is technically consistent with the Shapiro holding, it flies in the face of the concerns underlying Shapiro. Neither of the Wisconsin statute's gimmicks altered the fact that some newcomers were being "denied welfare aid upon which may depend [their] ability ... to obtain the very means to subsist-food, shelter, and other necessities of life."71 This was precisely the problem that had led the Shapiro Court to characterize the welfare waiting periods in that case as penalties subject to strict scrutiny. ${ }^{72}$ As the Jones dissent pointed out, "[s]ixty days without food and shelter is no less devastating than one year without food and shelter."

Moreover, Shapiro had already established that "a State may no more try to fence out those indigents who seek higher welfare benefits than it may try to fence out indigents generally." quently, the Wisconsin legislature had in mind a clearly impermissible purpose-excluding higher benefit-seeking indigents from the state-when it enacted the sixty-day waiting period. Nevertheless, the waiting period remains in force, symbolizing both political and judicial discontent with the Shapiro doctrine.

2. The Minnesota approach: giving newcomers what they received in their previous states of residence.

Minnesota offers welfare benefits comparable to Wisconsin's. ${ }^{75}$ In 1991, the Minnesota legislature also passed a law that provided

69 Jones, 485 NW2d at 26.

${ }^{20}$ Id.

71 Shapiro, 394 US at 627.

72 Id.

73 Jones, 485 NW2d at 30 (Heffernan dissenting).

34 Shapiro, 394 US at 631.

75 As of January 1990, Minnesota was the ninth most generous state, providing a maximum of $\$ 532$ in AFDC benefits to a family of three. Green Book at 561-62 (cited in note 63). In addition, Minnesota provides state-funded "general assistance" and "work readiness" benefits. See Mitchell $v$ Steffen, 487 NW2d 896, 900 (Minn App 1992). The discussion in the following text applies equally to the California waiting period. See Cal Welf \& Inst Code 
lower benefits to newcomers. ${ }^{76}$ But facing the same dictates of Shapiro, Minnesota declined to completely eliminate welfare for newcomers. The state opted instead to limit welfare payments to new residents during their first six months of residence in Minnesota to the amount they had received in their previous states of residence. ${ }^{77}$ This system allowed Minnesota to claim that it was not attempting to deter travel; it merely wanted to avoid providing an incentive for people to move into the state for the sole purpose of obtaining higher welfare benefits. ${ }^{78}$

An examination of the Minnesota waiting period under current Supreme Court jurisprudence leads to the inevitable conclusion that it, like the Wisconsin version, penalizes the exercise of the right of interstate travel. Although new residents may be no worse off financially in Minnesota than they were in their previous states of residence, Soto-Lopez (interpreting Zobel) established that this fact is irrelevant. ${ }^{79}$ Whether a statute deters travel is only one consideration in the penalty analysis-lack of a deterrent effect is not dispositive. The core guarantee of the right to travel as interpreted by the Supreme Court is that it "insur[es] new residents the same right to vital government benefits and privileges in the States to which they migrate as are enjoyed by other residents." 80 The Minnesota statute gives new residents lower benefits than long-time residents-benefits necessary by definition "to

$\S 11450.03$. California ranked second in 1990 , with a $\$ 694$ AFDC check allotted to each family of three. Green Book at 561-62.

${ }_{78}$ See Minn Stat Ann § 256D.065.

${ }_{77}$ Id. Obviously, if the old state's payments were higher than the Minnesota maximum, the new resident would receive the latter. Id. Moreover, any new resident would be eligible for at least 60 percent of the Minnesota maximum. Id. California imposed a similar one-year waiting period on new residents, Cal Welf \& Inst Code $\S 11450.03$, but the California statute lacks the $60 \%$ provision.

The Illinois legislature enacted a similar statute in 1992. See 305 ILCS 5/11-30 (1992). It established a one-year waiting period applicable to all public assistance. Illinois has not fully implemented the statute, however, because the United States Department of Health and Human Services has not granted the Illinois Department of Public Aid the federal waivers necessary to apply this statute to its AFDC and Medicare programs. See id; conversation with David Peterson, Deputy General Counsel for the Illinois Department of Public Aid (Oct 6, 1993). Illinois has implemented the waiting period for general assistance, see $1993 \mathrm{III}$ Rgtr 6814 (1993), to be codified at 89 Ill Admin Code 114.406, and for Aid to the Aged, Blind, and Disabled, see 1993 Ill Rgtr 6804 (1993), to be codified at $89 \mathrm{Ill}$ Admin Code $113.309,113.450$, because these two programs are entirely state-funded.

${ }^{78}$ See Mitchell, 487 NW2d at 901-02. See also Green v Anderson, 811 F Supp 516, 522 n 14 (E D Cal 1993).

${ }^{79}$ See text accompanying note 54 .

${ }^{80}$ Memorial Hospital, 415 US at 261. 
maintain a subsistence reasonably compatible with decency and health"81_ and therefore penalizes travel.

Further, Minnesota's purpose in enacting its durational residency requirement was constitutionally impermissible. A state may no more intentionally remove an incentive to migrate (without canceling the corresponding benefit for long-time residents) than it may try to deter migration through similar means. ${ }^{82}$ Adopting substantially the reasoning set forth above, the Minnesota Court of Appeals recognized the statute's constitutional defects and struck it down. ${ }^{83}$

\section{Alternative Approaches to Right to Travel Analysis}

Although the right to travel doctrine pioneered by Shapiro has remained intact for almost 25 years, it has always been controversial. The decision was greeted by a flurry of mostly disapproving law journal articles, ${ }^{84}$ and the stream of commentary continues to flow. ${ }^{\mathbf{8 5}}$ State legislatures have repeatedly challenged the right to travel doctrine. ${ }^{86}$ One state court saw fit to reduce the scope of the doctrine beyond what the language of Shapiro and its progeny reasonably permit. ${ }^{87}$ In fact, the Supreme Court itself has never achieved unanimity in deciding a right to travel case, nor has it applied the same approach in every case involving a durational residency requirement or similar law. ${ }^{88}$

Today, the right to travel doctrine is vulnerable to severe limi-

\footnotetext{
81 This is the level of support called for by the statute itself. Minn Stat Ann $\S 256 \mathrm{D} .01(1)$.

82 Or, as the court reviewing the California statute observed, "the State may not identify a group of current residents as its 'own' and seek to advance their interests and ... . address their needs to the detriment of new residents." Green, 811 F Supp at 522, citing Soto-Lopez, 476 US at 911.

${ }^{83}$ Mitchell, 487 NW2d at 907, California's waiting period was likewise invalidated, for similar reasons. See Green, 811 F Supp at 516, 522-23.

see, for example, Note, Constitutional Law-Equal Protection-The Welfare Residence Requirements, 44 Tulane L Rev 363 (1970); Comment, Constitutional Law-Equal Protection-Shapiro v. Thompson, 394 U.S. 618 (1969), 4 Suffolk U L Rev 573 (1970).

${ }^{8 s}$ See, for example, Katheryn D. Katz, More Equal than Others: The Burger Court and the Newly Arrived State Resident, 19 NM L Rev 329 (1989) (arguing that new residents enjoy unfairly favorable constitutional treatment).

ss See text accompanying notes 6-9.

37 See Jones, 485 NW2d 21; text accompanying notes 67-74.

${ }^{88}$ See Hooper v Bernalillo County Assessor, 472 US 612 (1985); Zobel v Williams, 457 US 55 (1982); Sosna v Iowa, 419 US 393 (1975).
} 
tation, ${ }^{89}$ if not to outright reversal..$^{90}$ Of the six justices who voted to strike down the employment preference in Soto-Lopez, only one remains on the Court.91 Yet all three Soto-Lopez dissenters are still active ${ }^{92}$ and the other five justices have yet to express an opinion on the matter. Consequently, the future of Shapiro is highly uncertain.

This uncertainty calls for an examination of alternative methods of analyzing durational residency requirements under the Constitution. Two possible approaches have attracted the support of current Supreme Court justices and accordingly deserve mention here.

\section{Chief Justice Rehnquist's ad hoc balancing test.}

Sosna $v$ Iowa involved an Iowa statute that required one year of continuous residence in Iowa before a petition for dissolution of marriage against a non-resident could be filed. ${ }^{93}$ In an opinion written by then Justice Rehnquist, the Court upheld the statute without specifying the standard of review. The decision appeared simply to balance, in an ad hoc manner, the state interests in favor of the statute against the burden on the right to travel, concluding that the former outweighed the latter. ${ }^{94}$

The Court distinguished Shapiro, Dunn, and Memorial Hospital with the observation that "the durational residency requirements they struck down were justified on the basis of budgetary or recordkeeping considerations ...."9s The state of Iowa, on the other hand, had more important interests to protect. It wanted to ensure recognition of its divorce decrees by other states under the Full Faith and Credit Clause of Article IV, $\S 1$ of the Constitu-

${ }^{89}$ For example, a court need only find, as in Jones, that a waiting period of shorter duration or narrower application than the ones reviewed in Shapiro does not penalize travel. The failure of the Shapiro line of cases to define the boundaries of penalty analysis makes such limitations possible.

${ }^{80}$ See Seth F. Kreimer, The Law of Choice and Choice of Law: Abortion, the Right to Travel, and Extraterritorial Regulation in American Federalism, 67 NYU L Rev 451, 460 (1992) ("[U]nder the Rehnquist Court, reliance on previous decisions has become a somewhat hazardous enterprise.").

91 Justice Blackmun.

'92 Chief Justice Rehnquist and Justices Stevens and O'Connor.

93 419 US 393,395 (1975).

Id at 406, 409-10.

85 Id at 406. 
tion. ${ }^{96}$ It did not wish to become a "divorce mill."97 Nor did it wish to intrude on the legitimate interests of other states in governing a proceeding with such momentous consequences for out-of-state parties. ${ }^{98}$ Thus, the Court reached a different outcome than it had in earlier right to travel cases.98

Because Sosna did not offer a systematic method of resolving right to travel disputes, it has had little effect on the outcome of subsequent cases. Lower courts have expressed confusion over how to interpret Sosna, ${ }^{100}$ while in Soto-Lopez a Supreme Court plurality passed over Sosna in a footnote. ${ }^{101}$ It is likely that the Sosna opinion represented little more than the "distaste for the mode of analysis [previously] applied to this corner of equal protection law"102 which Justice Rehnquist had revealed earlier in Memorial Hospital. ${ }^{103}$

2. Justice O'Connor's Privileges and Immunities Clause approach.

In Zobel $v$ Williams, the Court struck down an Alaska program that annually distributed a portion of the state's oil-reserve earnings in accordance with the duration of each citizen's residence. ${ }^{104}$ Newcomers thus received dividends in lesser amounts than more established residents. ${ }^{105}$ The Zobel Court held that this program had no permissible rational basis and therefore found no need to analyze whether it penalized the right to travel. ${ }^{106}$

Concurring in Zobel, Justice O'Connor suggested an entirely new approach to cases implicating the right to travel. ${ }^{107}$ Most jus-

o8 Id at 407-08. As the Court explained, when a divorce decree is entered after a finding of domicile in an ex parte proceeding, that finding is subject to collateral attack in other states. Id.

o7 Id at 407.

98 Id at 406-07.

90 Id at 409.

${ }^{100}$ See Redhail v Zablocki, 418 F Supp 1061, 1071 n 6 (E D Wis 1976) ("The substance of the [C]ourt's approach [in Sosna] defies simple characterization."); Hassan $v$ East Hampton, 500 F Supp 1034, 1041 (E D NY 1980) ("[T] he Sosna Court may have fueled the problem [of defining "penalize"] by refusing to apply a traditional equal protection analysis."); Joseph $v$ City of Birmingham, 510 F Supp 1319, 1335 n 23 (E D Mich 1981) (interpreting Sosna as foreshadowing a possible abandonment of penalty analysis).

${ }^{101}$ Soto-Lopez, 476 US at 905 n 5.

102 Sosna, 419 US at 419 (Marshall dissenting).

${ }^{303}$ See 415 US at 288 (Rehnquist dissenting).

104457 US 55 (1982).

105 Id at 57.

208 Id at 65.

${ }^{107}$ Id at 71-81 ( $0^{\prime}$ Connor concurring in the judgment). 
tices who had criticized the Shapiro line of cases at various times in dissenting and concurring opinions had complained that the Court had applied the wrong standard of review under the Equal Protection Clause or had applied the appropriate standard incorrectly. ${ }^{108}$ In contrast, Justice O'Connor grounded her approach in the Privileges and Immunities Clause of Article IV, § 2 of the Constitution. ${ }^{109}$ This view is controversial because the Privileges and Immunities Clause has traditionally been interpreted to protect nonresidents only. ${ }^{110}$ Justice O'Connor argued, however, that the protection continues after one establishes residency in a new state. "The fact that [] discrimination unfolds after the nonresident establishes residency does not insulate [state laws] from scrutiny under the Privileges and Immunities Clause."111

Under Justice O'Connor's privileges and immunities approach, a statute must satisfy a two-part test if it burdens a nonresident or new resident who seeks to engage in an "essential activity" or exercise a "basic right." 112 First, there must be "something to indicate that non-citizens constitute a peculiar source of the evil at which the statute is aimed." 113 Second, "the Court must find a 'substantial relationship' between the evil and the discrimination practiced against the noncitizens."114

Justice O'Connor's application of this test in Zobel was somewhat tortured. She argued that Alaska's dividend distribution scheme did burden an essential activity-settlement in a new state-and she therefore concurred in the Court's decision to strike down the scheme. ${ }^{115}$ In fact, Justice O'Connor took the position

${ }^{108}$ See, for example, Memorial Hospital, 415 US at 286 (Rehnquist dissenting) (asserting that the Court should give "traditional respect" to waiting period for county-funded, non-emergency medical care); Sosna, 419 US at 420 (Marshall dissenting) (arguing that the compelling interest test should apply to statute requiring a year of state residency prior to filing a divorce petition).

${ }^{108}$ Zobel, 457 US at 73-74.

110 See id at $84 \mathrm{n} 3$ (Rehnquist dissenting), citing Toomer $v$ Witsell, 334 US 385, 395 (1948).

${ }^{111}$ Zobel, 457 US at 75 (O'Connor concurring).

122 Id at 76, citing Baldwin v Montana Fish and Game Comm'n, 436 US 371, 387 (1978). This is the standard test applicable to all statutes reviewed under the Privileges and Immunities Clause. See Hicklin v Orbeck, 437 US 518, 525-27 (1978).

${ }^{113} \mathrm{Zobel}, 457$ US at 76, quoting Hicklin, 437 US at 525-26.

114 Zobel, 457 US at 76, quoting Hicklin, 437 US at 527.

136457 US at 76-78. This reasoning is questionable. The activity arguably burdened was not settlement, but rather the fortuitous receipt of oil dividends, and the unequal distribution of this windfall did not burden new residents in any practical sense. Nonetheless, Justice 0 'Connor concluded that the burden was to be measured "relative to the benefits enjoyed by [long-time] residents." Id at $76 \mathrm{n} 6$. 
that any statute that favors long-time residents over newcomers burdens settlement. Under this view, every durational residency requirement or similar statute burdens an essential activity and must be subjected to the same two-part test. ${ }^{116}$

Justice O'Connor has not held to this rigid position. In SotoLopez, for example, she voted to uphold the civil service employment preference because it had only a "minimal effect" on the right to travel and did not threaten the constitutional purpose of "maintaining a Union rather than a mere 'league of States." "117 She did not make clear why she considered the deprivation of an employment preference to have a lesser effect on travel than deprivation of the oil dividend in Zobel.

Although Justice O'Connor's concurring opinion in Zobel represented her views alone, Justice Stevens and Chief Justice Rehnquist joined her Soto-Lopez dissent. If two of the five currently uncommitted justices were to add their votes, the Privileges and Immunities Clause approach could replace traditional right to travel doctrine. Adopting this approach, however, would require an important expansion of the Clause to cover new residents as well as nonresidents, ${ }^{118}$ a step the Court might not be willing to take. ${ }^{119}$

\section{According Quasi-Suspect Treatment to Classifications That Burden Poverty-Stricken New Residents}

Chief Justice Rehnquist and Justice O'Connor have made important contributions to the right to travel debate, but they cannot yet claim victory for their respective positions. The question remains where the Court would turn if it were to abandon Shapiro's analysis of durational residency requirements. This Section will propose a third approach. It will argue that impoverished new resi-

116 See id at $78 \mathrm{n} 8$, acknowledging this point but pointing out that some durational residency requirements would still survive analysis. For example, in Sosna, nonresidents were a peculiar source of the evil addressed by the requirement because they could misrepresent their attachment to Iowa and obtain divorces that would be subject to collateral attack. Id. One commentator has argued, relying on the Privileges and Immunities Clause, that durational residency requirements are permissible only when they respond to a reasonable concern for proof of domiciliary intent. See William Cohen, Equal Treatment for Newcomers: The Core Meaning of National and State Citizenship, 1 Const Comm 9, 19 (1984).

11776 US at 923-24, 925.

118 See text accompanying notes 110-11.

110 See, for example, Zobel, 457 US at 84 n 3 (Rehnquist dissenting) (stating the Privileges and Immunities Clause "has no application to a citizen of the State whose laws are complained of"). This issue did not arise in Justice O'Connor's Soto-Lopez dissent, which then Justice Rehnquist joined, though it was present in the case. At the time of the suit, Soto-Lopez was a "citizen of the State whose laws [were] complained of." 
dents of a state should be treated as a "quasi-suspect" class for the purposes of Equal Protection review. Welfare waiting periods, which put new residents at a disadvantage relative to long-time residents, should therefore be subjected to "intermediate scrutiny"-a form of heightened scrutiny that takes into account the special characteristics of poor newcomers while recognizing that they do not warrant the strict scrutiny protection afforded to traditionally suspect classes.

\section{A. Basic Principles of "Suspect Class" Doctrine}

As stated earlier, courts apply strict equal protection scrutiny when a statute discriminates against a "suspect" class, such as a particular racial group. The courts could conceivably have limited such special treatment to statutes aimed at African-Americans, given the history of the Fourteenth Amendment. ${ }^{120}$ Instead, the Court has broadened the scope of the Equal Protection Clause to safeguard the rights of any group with characteristics "so seldom relevant to the achievement of any legitimate state interest that laws grounded in such considerations are deemed to reflect prejudice and antipathy." 121 Thus, any classification based on race or national origin is considered suspect and must pass strict scrutiny to survive. ${ }^{122}$

Classifications that are not based on race or national origin need not withstand strict scrutiny. However, if a classification singles out for differential treatment a "quasi-suspect" class ${ }^{123}$ - a class that shares many, if not all, of the relevant characteristics that give racial and national groups their suspect nature-the classification must survive some form of heightened review more stringent than mere "rational basis" review. The standards for quasi-

${ }^{120}$ See Slaughter-House Cases, 83 US (16 Wall) 36, 71 (1873).

${ }^{221}$ City of Cleburne $v$ Cleburne Living Center, 473 US 432, 440 (1985).

${ }^{122}$ Loving $v$ Virginia, 388 US 1, 11 (1967) (race); Oyama v California, 332 US 633, 646 (1948) (national origin); Korematsu v United States, 323 US 214, 216 (1944) (race and national origin). The Court has also indicated in dicta that religion is a suspect criterion. See New Orleans v Dukes, 427 US 297, 303 (1976).

${ }_{123}$ "Quasi-suspect" is a catch-all term. It describes groups that, while meriting more than rational basis review, lack some of the characteristics that have moved the Court to grant full suspect status to racial and national groups. Currently, this includes gender groups, illegitimate children, and possibly aliens. See, for example, Cleburne, 473 US at 44042. The Court does not apply the same standard of review to each group. See notes 124-25.

The term "quasi-suspect" first appeared in a dissenting opinion by Justice Marshall, Massachusetts Board of Retirement v Murgia, 427 US 307, 325 (1976) (Marshall dissenting), and has since found recognition in Supreme Court majority opinions, see Cleburne, 473 US at 442; Lyng $v$ Castillo, 477 US 635, 638 (1986). 
suspect classes are collectively dubbed "intermediate scrutiny." The Court has already granted quasi-suspect treatment to genderand illegitimacy-based classifications, ${ }^{124}$ and at least some extra protection to aliens. ${ }^{125}$ In addition, wealth-based classifications were once viewed with some suspicion. ${ }^{126}$

When the Court has chosen not to treat a group as a suspect or quasi-suspect class, it has explicitly based its decision on that class's lack of some attribute that would make the class more suspect. ${ }^{127}$ The Court's consistency in dealing with "suspect class" claims suggests that in every equal protection case a court should inquire whether the aggrieved class qualifies as suspect by examining it for the relevant characteristics. ${ }^{128}$ Welfare waiting periods single out for disfavored treatment the class of new state residents who have applied for public assistance benefits. ${ }^{129}$ If these new state residents constitute a suspect or quasi-suspect class, heightened scrutiny of some sort (either strict scrutiny or intermediate scrutiny) will be appropriate even if a court rejects the right to travel argument. ${ }^{130}$

New residents in general should not be labelled as "suspect" because they lack several of the characteristics that typify suspect

124 For the Court to uphold a gender classification, it must be "substantially related" to an "important governmental interest." See, for example, Mississippi University for Women v Hogan, 458 US 718, 724 (1982). One that turns on illegitimacy must be "substantially related to a legitimate state interest." Mills $v$ Habluetzel, 456 US 91, 99 (1982).

${ }^{125}$ The Supreme Court has been inconsistent in its treatment of aliens, according them the protection of strict scrutiny in Graham $v$ Richardson, 403 US 365, 372 (1971) (welfare benefits limited to persons resident in the United States for certain numbers of years), but only rational basis review in Cabell $v$ Chavez-Salido, 454 US 432, 439 (1982) (peace officers required to be United States citizens). See generally Laurence H. Tribe, American Constitutional Law \& 16-23 at 1544-53 (Foundation, 2d ed 1988).

${ }^{128}$ See, for example, Harper v Virginia Board of Elections, 383 US 663, 670 (1966) (invalidating state poll tax). The Court distanced itself from this position in Maher $v$ Roe, 432 US 464, 470-71 (1977) (upholding state's denial of Medicaid funding for abortion), and San Antonio Independent School District v Rodriguez, 411 US 1, 29 (1973) (upholding state's system of funding public schools where funding depended on locally taxable wealth).

${ }^{127}$ See, for example, Cleburne, 473 US at 442-43; Castillo, 477 US at 638.

${ }^{128}$ But see, for example, Ben-Shalom v Marsh, 881 F2d 454, 464 n 8 (7th Cir 1989) (declaring that strict and intermediate scrutiny are "presently reserved for classifications by race, alienage, national origin, gender and illegitimacy") (emphasis added).

${ }^{120}$ See Shapiro, 394 US at 627.

${ }^{130}$ In fact, one commentator has suggested that the outcomes of the Supreme Court's right to travel cases were unconsciously motivated by the view that new residents deserve suspect class treatment. See Thomas R. McCoy, Recent Equal Protection Decisions-Fundamental Right to Travel or "Newcomers" as a Suspect Class?, 28 Vand L Rev 987, 1006-07 \& n 87 (1975). See also Troyer v Town of Babylon, 483 F Supp 1135, 1140 (E D NY 1978) (stating that an ordinance based on residence "creates a suspect classification and must be shown to be necessary to further a compelling state interest"). 
classes. Given that the courts, and the Supreme Court in particular, have been reluctant to expand the number of categories recognized as suspect, the argument in favor of any suspect treatment for all new residents lacks plausibility. ${ }^{131}$ Thus, strict or intermediate scrutiny should not automatically apply to every durational residency requirement.

Welfare waiting periods are another matter, however. They affect not new residents in general, but rather only indigent newcomers. Although poverty alone is not a suspect criterion, when combined with recent arrival in a new state it may assume this quality. Full suspect treatment, on a par with that accorded racial and national groups, would be excessive, ${ }^{132}$ but some heightened scrutiny-intermediate scrutiny-should be provided for welfare waiting periods. The logic of this view becomes evident upon a review of the common characteristics of suspect and quasi-suspect classes.

\section{B. Defining "Suspect"}

To determine whether indigent new residents are sufficiently comparable to the traditional suspect or quasi-suspect classes to merit equivalent protection, it is necessary to identify the relevant criteria. The classic formulation for suspect classes comes from footnote four in United States $v$ Carolene Products Co., which suggested that exacting judicial scrutiny applies when prejudice against "discrete and insular minorities" is involved. ${ }^{133}$ Later decisions reflect additional concerns not captured by this phrase. ${ }^{134}$ It will be instructive to lay out these concerns in detail. All of them suggest to greater or lesser degrees that a particular classification is suspect when it is the product of prejudice rather than a rational attempt to achieve a legitimate goal.

Two variables in particular best explain the Court's scheme for identifying the appropriate standard of review. Every suspect or quasi-suspect class has suffered a history of irrational discrimi-

${ }^{131}$ For an in-depth argument that the Supreme Court has accorded new residents too much protection, see Katz, 19 NM L Rev 329 (cited in note 85).

${ }^{132}$ See id at 359.

${ }^{\text {xs }} 304$ US 144, 152-53 n 4 (1938). The Carolene Products Court reasoned that such prejudice "tends seriously to curtail the operation of those political processes ordinarily to be relied upon to protect minorities . . . ." In other words, prejudice may prevent certain groups from adequately defending their political interests in the pluralist political bargaining that typifies modern American politics.

${ }^{134}$ For a critique of the "discrete and insular" formulation, see Bruce A. Ackerman, Beyond Carolene Products, 98 Harv L Rev 713 (1985). 
nation that continues into the present. Each is likewise free of attributes that readily justify differential treatment at the hands of the state. ${ }^{135}$ In contrast, each group that has been denied suspect or quasi-suspect status either has suffered no history of discrimination, or is marked by "real differences," or both.

\section{Historical discrimination.}

Perhaps the most obvious indicator of a suspect class is a history of pervasive and irrational discrimination. ${ }^{136}$ If it can be shown that a group has been mistreated in the past and that hostility toward the group persists, it will become more likely that prejudice lurks behind any act injurious to the group. ${ }^{137}$ Of course, this factor alone cannot explain all of the Court's decisions. The Court subjects all race-based classifications to strict scrutiny, even those that operate to the disadvantage of traditionally privileged groups. ${ }^{138}$ On the other hand, statutes based on gender undergo only intermediate scrutiny even though women have a history of discrimination similar to that of African-Americans. ${ }^{139}$ Likewise, the Court has failed to extend suspect status to homosexuals or the mentally retarded, despite historical discrimination against these groups. ${ }^{140}$

${ }^{135}$ At this point, one might ask how quasi-suspect classes differ from suspect classes. The Supreme Court has never adequately explained the distinction. However, several explanations present themselves. First, the history of the Fourteenth Amendment indicates a special concern for certain classifications, namely those based on race. See Trimble $v$ Gordon, 430 US 762, 777 (1976) (Rehnquist dissenting). Second, quasi-suspect classes may exhibit some "real differences" that justify different treatment in limited circumstances. See text accompanying notes 141-46. Finally, suspect classifications may ultimately be sui generis because they are "so historically untenable, so dangerous, and so tied to perpetuation of violence and degradation of the very classes of human beings who are least equipped to respond . . ." Mari J. Matsuda, Legal Storytelling: Public Response to Racist Speech: Considering the Victim's Story, 87 Mich L Rev 2320, 2357 (1989) (arguing that racist speech should be treated as a sui generis category and denied full First amendment protection).

${ }^{138}$ See Castillo, 477 US at 638; Mathews v Lucas, 427 US 495, 506 (1976); Rodriguez, 411 US 1, 28 (1973). See also McCoy, 28 Vand L Rev at 1018-19 (cited in note 130).

${ }^{137}$ See City of Richmond v J.A. Croson Co., 488 US 469, 493 (1989).

${ }_{138}$ See id at 493-94; University of California Regents v Bakke, 438 US 265, 291 (1978); Fullilove v Klutznick, 448 US 448, 491-92 (1980). At a minimum, however, even privileged groups may be the victims of stereotyping by others. See, for example, Croson, 488 US at 516 (Stevens concurring in part and concurring in the judgment).

${ }^{139}$ See Frontiero v Richardson, 411 US 677, 684-86 (1973) (plurality opinion). Four justices argued that women should be viewed as a suspect class. This view has never gained the support of a majority on the Court. See Craig $v$ Boren, 429 US 190, 204 (1976).

${ }^{140}$ See Bowers v Hardwick, 478 US 186 (1986) (homosexuals); Cleburne, 473 US at 446 (mentally retarded). With respect to the mentally retarded, the Court found that, despite 


\section{2. "Real differences."}

The Court has also looked to whether members of a class exhibit "real differences": traits that would justify differential or discriminatory treatment by the state. If the class manifests no such real differences, the classification is suspect. If, on the other hand, the group does exhibit substantial real differences, the classification likely will be spared suspect treatment. ${ }^{141}$ For example, the Court did not extend heightened review to the mentally retarded because "legislation [ ] singling out the retarded for special treatment reflects the real and undeniable differences between the retarded and others."142 For similar reasons, the Court found that age-based classifications were not suspect. ${ }^{143}$ This factor may also partially explain why statutes that disfavor women, aliens, and illegitimate children are subject to intermediate scrutiny rather than strict scrutiny. In the case of women, "deeply-held cultural norms and biological dissimilarities" may justify a lower standard in the Court's view. ${ }^{144}$ Aliens' potential loyalty to foreign governments may justify different treatment, at least in some circumstances. ${ }^{146}$ And because the bonds between parents and illegitimate children may be more tenuous than in other parent-child relationships, different treatment of illegitimate children also faces a lower standard. ${ }^{146}$

\section{Other factors.}

The Court has found other factors to be relevant to the "suspect" inquiry, but these are less conclusive. While the applicability of a particular element may strengthen a group's claim for suspect or quasi-suspect treatment, in no case will it assure success. Nor is

past mistreatment, more recently "lawmakers have been addressing [the] difficulties [of the retarded] in a manner that belies a continuing antipathy or prejudice . . . " Id at 443.

${ }^{141}$ See Cleburne, 473 US at 440; Rodriguez, 411 US at 121-22 (Marshall dissenting); McLaughlin v Florida, 379 US 184, 192 (1964).

${ }^{142}$ Cleburne, 473 US at $442-44$.

${ }^{143}$ See id at 441-42, explaining Massachusetts Board of Retirement v Murgia, 427 US 307 (1976).

${ }^{144}$ Comment, Toward Gender Equality: Testing the Applicability of a Broader Discrimination Standard in the Workplace, 40 Buff L Rev 217, 219 (1992).

${ }_{145}$ See Hampton v Mow Sun Wong, 426 US 88, 104 (1976) (striking down civil service regulations barring aliens for fear of foreign loyalties, but noting that barring aliens from higher-level positions could be justified on the same basis).

${ }^{146}$ See Lalli $v$ Lalli, 439 US 259 (1978) (upholding state law requiring illegitimate children to obtain court order declaring paternity to inherit from intestate father); Mathews $v$ Lucas, 427 US 495 (1976) (upholding Social Security Act provision requiring illegitimate children to prove dependency before receiving insurance upon death of parent). 
any one element indispensable to a finding that a class is suspect. $A$ list and brief explanation of these elements follows.

a) Discreteness. Part of the Carolene Products formulation, discreteness has been more descriptively termed the existence of "obvious . . . or distinguishing characteristics."147 Such characteristics cannot be hidden and therefore prevent members of the unpopular group from avoiding prejudice. ${ }^{148}$ Note that alienage and illegitimacy are nondiscrete but suspect characteristics, while age and mental retardation are discrete but nonsuspect. ${ }^{140}$

b) Insularity. The other half of the Carolene Products formula, insularity, refers to groups that are isolated or detached from the rest of society. Such isolation denies them influence over the groups that possess dominant political and economic power and cripples their ability to engage successfully in political bargaining. ${ }^{150}$ The courts rarely discuss this factor explicitly. Indeed, it would be difficult to argue that racial groups, women, or illegitimate children are "held at arm's length" by dominant groups or that homosexuals are not. ${ }^{151}$

c) Political powerlessness. If a group lacks political power, it cannot adequately defend its interests in the political arena. ${ }^{152}$ Legislative initiatives based on prejudice against the group will be more likely to succeed. This factor fails, however, to distinguish suspect classes from most other losers in politics. Fur-

${ }^{147}$ Castillo, 477 US at 638. For example, skin color and foreign language are qualities that make a group discrete. Homosexuality is not such a quality because it can be hidden. See Ackerman, 98 Harv L Rev at 729 (cited in note 134).

${ }^{148}$ One would expect that this factor would become less important for non-discrete but verifiable characteristics, such as alienage. When people must come forward to claim a benefit, and in the process declare whether they possess the attribute in question, discrimination is no less feasible than if members of the class were discrete.

${ }^{140}$ But see Graham $v$ Richardson, 403 US 365, 372 (1971), which held that aliens were "a prime example of a 'discrete and insular' minority . . . ." This holding was criticized by Professor Louis Lusky, who clerked for Justice Stone when Stone authored Carolene Products, in Footnote Redux: A Carolene Products Reminiscence, 82 Colum L Rev 1093, $1105 \mathrm{n}$ 72 (1982).

${ }^{180}$ See Lusky, 82 Colum L Rev at 1105 n 72.

${ }^{151}$ See id (discussing ethnic groups).

${ }_{162}$ See Rodriguez, 411 US at 28 (discussing classes "relegated to such a position of political powerlessness as to command extraordinary protection from the majoritarian political process"). In this context, political powerlessness may arise not only from the lack of elected representatives, but also from the representatives' lack of influence in the political bargaining process due to prejudice on the part of the majority. See Ackerman, 98 Harv L Rev at 732 (cited in note 134). 
thermore, the political power of some traditionally suspect classes has increased greatly in the past few decades without any effect on their status under the Equal Protection Clause. ${ }^{183}$

d) Immutability. Immutability describes characteristics over which a person has no control or that are "so central to a person's identity that it would be abhorrent for government to penalize a person for refusing to change them, regardless of how easy that change might be physically."154 Its relevance may stem in part from the notion that "political majorities can be trusted least when they act to burden minority groups to which they never belonged and from which they will always be excluded."15s In addition, it seems unfair to punish a person based on a quality for which he is not responsible. ${ }^{156}$ Note that alienage is not immutable, since immigration is a voluntary act and aliens can eventually seek naturalization. In contrast, mental retardation and possibly homosexuality are immutable characteristics.

e) Risk of stigma. If a classification serves to stereotype and stigmatize a group based on its distinguishing attributes, the Court has indicated that strict or intermediate scrutiny is appropriate. ${ }^{157}$

\section{New Indigent Residents as a Suspect Class}

The Court has never definitively stated what combination of the above factors will bring about heightened scrutiny. It is therefore impossible to predict with confidence how the Court will rule in an individual case. ${ }^{158}$ Nevertheless, a comparison of indigent

${ }^{163}$ See, for example, Richard M. Burkey, Racial Discrimination and Public Policy in the United States ch 3 at 36-37 (Heath Lexington, 1971) (describing African-Americans' increasing political power since World War II).

${ }^{354}$ Watkins v United States Army, 847 F2d 1329, 1347 (9th Cir 1988), opinion withdrawn on rehearing, 875 F2d 699, 711 (1989).

${ }_{186}$ Tribe, Constitutional Law $\S 16-23$ at 1545 n 5 (cited in note 125). See also McCoy, 28 Vand L Rev at 1019 (cited in note 130).

${ }^{158}$ See Mathews $v$ Lucas, 427 US 495, 505 (1976), citing Weber v Aetna Casualty \& Surety Co., 406 US 164, 175 (1972).

${ }_{157}$ See Bakke, 438 US at 360 (opinion of Brennan, White, Marshall, and Blackmun) (warning that even "benign" discrimination can preserve the social stigma of minorities); Frontiero $v$ Richardson, 411 US 677, 684-85 (1973) (plurality opinion) (gender).

${ }^{168}$ Actually, it would be foolish to expect the Court to recognize an additional suspect class in the near future. Justice Marshall complained in one dissenting opinion that "the Court . . . has apparently lost interest in recognizing further . . . 'suspect' classes." Murgia, 427 US at 318-19 (Marshall dissenting). In fact, the Court has not expanded the category of suspect classes since the 1960s. 
newcomers with those groups that have already been granted or denied quasi-suspect status suggests that indigent newcomers have more in common with the former than the latter. ${ }^{158}$

First, indigent migrants have long been the victims of antipathy in the communities where they have attempted to settle. The sorry history of official discrimination against indigent migrants dates back to the colonial period, when potential public charges were "warned out" of towns. ${ }^{160}$ As Professor Friedman has noted, "[k]indly impulses were expended on friends and neighbors who fell on evil days. There the sympathy stopped." ${ }^{161}$ Hostile attitudes predominated during the nineteenth century as well, when each town was expected to care for its own poor and could be sued if another town was forced to support one of its paupers. ${ }^{162}$ Such attitudes have persisted, as evidenced by the existence of welfare waiting periods on the statute books of all but four states prior to the Shapiro decision ${ }^{\mathbf{1 6 3}}$ and the current fear among established Wisconsin and California residents that these states have become "welfare magnets."164

The general class of new residents can make no claim to such a history. The large number of durational residency requirements past and present likely reflects in-staters' greed as much as prejudice toward newcomers. True, some communities may dislike all outsiders, especially communities that are traditionally small and insular ${ }^{165}$ or are experiencing a large influx of newcomers. ${ }^{168}$ However, this is no longer the norm. Today's increasingly urban society is becoming more mobile and impersonal. ${ }^{167}$ People are less

\footnotetext{
189 This Comment will assume that indigent newcomers are not a fully suspect class for the reasons stated in note 135 .

${ }^{160}$ Shapiro, 394 US at 628 n 7; Lawrence M. Friedman, A History of American Law 8990 (Simon \& Schuster, 2d ed 1985). For a more extensive discussion of discrimination against indigent newcomers, see Margaret $\mathrm{K}$. Rosenheim, Shapiro v. Thompson: "The Beggars are Coming to Town", $1969 \mathrm{~S}$ Ct Rev 303, 307-15.

161 Friedman, A History of American Law at 90.

162 Id at 214-15, 492.

${ }^{203}$ Shapiro, 394 US at $676 \mathrm{n} 36$ (Harlan dissenting).

164 Peterson and Rom, Welfare Magnets at 26-32 (cited in note 17) (discussing the politicization of welfare payment levels in Wisconsin).

${ }^{10 s}$ See, for example, Jeff Kunerth, Small Towns Find Nostalgia a Ready Resource to Exploit, Orlando Sentinel Tribune A11 (May 28, 1990) (Southern town residents' dislike of outsiders); Charles Hillinger, Content Vermonters Keep Clock Turned Back, LA Times F18 (Apr 21, 1985) (same for Vermont residents).

${ }^{166}$ See, for example, The Northwest: Colonised, The Economist 26 (July 22, 1989) (discussing distaste in Oregon and Washington for newcomers from California).

${ }^{167}$ See Ronald L. Warren, The Community in America 83-84 (Rand McNally, 1963) (describing the transient nature of suburban life, despite residents' attempts to create tighter-knit communities).
} 
concerned about the origin of their neighbors. Even in more tightly knit communities, the popular image of the welcome wagon belies the assertion that new residents are systematically ill-treated.

Another consideration supporting intermediate scrutiny for laws penalizing indigent newcomers is the fact that a person's status as an indigent newcomer is generally irrelevant as a basis for legislative action. In other words, this class exhibits no "real differences." Although legislation frequently discriminates against poor people $^{168}$ or newcomers ${ }^{168}$ generally, welfare waiting periods are probably the only statutes that isolate the narrower class of indigent newcomers for separate treatment. ${ }^{170}$

Indigent newcomers also exhibit several of the other, less important, elements of a suspect class. First, they constitute a discrete minority, at least for the purposes of public assistance, because length of residence can be verified by welfare program administrators. ${ }^{171}$ Second, they lack political clout. When they arrive in their new state, the welfare waiting period is already in place, before they have had any opportunity to participate in the state's political process. State law may also prohibit them from voting for up to fifty days after they establish residency. ${ }^{172}$ Third, while neither new residence nor poverty is strictly immutable, ${ }^{173}$ "no significant number of the political majority run the risk of falling into the class of indigent newcomers as a result of changing circumstances."174 Finally, membership in the class of indigent newcomers carries a clear stigma. Welfare waiting periods convey the unambiguous message that such people are resented and unwelcome among their fellow state residents.

In short, indigent newcomers have all the necessary attributes of a quasi-suspect class. If any doubt persists as to the propriety of intermediate scrutiny for welfare waiting periods, the importance

${ }^{268}$ See Harry Simon, Towns without Pity: A Constitutional and Historical Analysis of Official Efforts to Drive Homeless Persons from American Cities, 66 Tulane L Rev 631 (1992).

${ }^{160}$ See McCoy, 28 Vand L Rev 987 (cited in note 130).

170 One might contend that this fact points away from heightened scrutiny. How can they be a suspect group if they face no other official discrimination? The answer is simple: they present a special threat only when they ask for aid.

171 See note 148.

${ }_{172}$ See Marston v Lewis, 410 US 679 (1973) (per curiam); Burns v Fortson, 410 US 686 (1973) (per curiam). These cases both upheld 50-day voter residency requirements as necessary to serve the states' interest in accurate voter lists.

${ }^{173}$ New residents, of course, become old residents after a certain time. Poverty can in theory be escaped.

${ }_{174}$ See McCoy, 28 Vand L Rev at 1019 (cited in note 130). 
of welfare benefits to the individuals concerned should eradicate it. ${ }^{176}$ What remains to be seen is whether welfare waiting periods are constitutional under this standard of review.

\section{Welfare Waiting Periods Under Intermediate Scrutiny}

When a reviewing court finds that a statute burdens a quasisuspect class and therefore examines the statute under intermediate scrutiny, the statute must possess a number of features in order to stand. These features include an "important" government interest that the statute purportedly furthers, ${ }^{178}$ a close fit between the statutory rules and the asserted interest, ${ }^{177}$ the existence of an opportunity for rebuttal in individual cases, ${ }^{178}$ and factual support for the policy decisions behind the statute. ${ }^{179}$

The Minnesota welfare waiting period, which denies equal welfare benefits to all newcomers regardless of individual circumstances, fails the test. A permissible waiting period might instead be based on a modified version of the Wisconsin model, which seeks to grant equal benefits to all except those with a mentality of dependency whose only reason for moving into the state is to receive higher benefits.

\section{A. Identifying an Important Interest}

To justify their welfare waiting periods, states have offered numerous governmental interests. Some serve no purpose other than "administrative convenience" and are easily dismissed under intermediate scrutiny. ${ }^{180}$ The Court has found other asserted interests to be illegitimate, subject to invalidation regardless of the standard of review. ${ }^{181}$ Only in a few cases has the Court found a

${ }^{178}$ See, for example, Plyler $v$ Doe, 457 US 202, 221-24 (1982) (applying intermediate scrutiny to a statute that denied education to children of illegal aliens, due in part to importance of education).

${ }^{178}$ Craig $v$ Boren, 429 US 190, 197 (1976).

177 Mississippi University for Women v Hogan, 458 US 718, 724 (1982).

${ }_{178}$ See Frontiero v Richardson, 411 US 677, 683-84 (1973) (plurality opinion).

${ }^{179}$ See, for example, Cleburne, 473 US at 458 (Marshall dissenting); Craig, 429 US at 199.

${ }^{180}$ See Wengler v Druggists Mutual Insurance Co., 446 US 142, 151-52 (1980) (administrative convenience insufficiently important to sustain gender-based classification); Craig, 429 US at 198 (same). In the welfare context, administrative objectives offered by the states include facilitating the planning of the welfare budget and providing an objective test of residency. See Shapiro, 394 US at 634 (applying strict scrutiny).

${ }^{181}$ This category includes attempts to deter migration of poor people into a state, Shapiro, 394 US at 629-31, and to distinguish between old and new residents based on the contribution they have made to the state. Id at 632-33; Zobel, 457 US at 68. 
sufficiently important state interest and had to move on to the next steps of the analysis. ${ }^{182}$

The interest that appears to drive most of the recent durational residency requirements is the state's desire to avoid becoming a "welfare magnet." States with generous welfare benefits fear that they attract indigents whose sole purpose for relocating is the promise of a fatter welfare check. Assuming for the moment that this concern has some basis in fact, it deserves closer examination than the Court has yet deigned to give it. In Shapiro, the Court stated in dictum that "a State may no more try to fence out those indigents who seek higher welfare benefits than it may try to fence out indigents generally." ${ }^{183}$ However, this position ignores the fact that most welfare programs are designed, not just to provide aid, but to encourage eventual self-support. ${ }^{184}$ Given these dual goals, it is reasonable for a state to deny aid to residents who intend to remain dependent on aid indefinitely. This may include newcomers chasing higher welfare benefits. ${ }^{185}$ Even the Shapiro Court felt compelled to qualify its position by stating that a person "should [not] be regarded as less deserving because she considers, among other factors, the level of a state's public assistance."186 This formulation, of course, skirts the issue of a person whose decision to relocate is based only on the level of a state's public assistance.

The resulting question, then, is whether a state's interest in encouraging employment is sufficiently important to satisfy intermediate scrutiny. Although the Court has held this interest to be adequate under "rational basis" review, ${ }^{187}$ it has not addressed whether it is "important" for the purposes of intermediate scrutiny. Nonetheless, when compared to state objectives the Court has recognized as substantial, such as enhancing traffic safety, ${ }^{188}$ en-

${ }^{182}$ The Court has eventually found such interests to be defective as well for want of the necessary "rational relationship" between the asserted interest and the waiting period. For example, a state has a legitimate interest in conserving limited state funds, but this interest does not explain why new residents, as opposed to some other group, should be singled out to receive lower benefits. See Plyler, 457 US at 227 . Nor can a state's valid interest in preventing welfare fraud justify a waiting period, because states already have other adequate, "less drastic" procedures in place to accomplish this purpose. Shapiro, 394 US at 637 (applying strict scrutiny).

${ }_{183} 394$ US at 631.

184 See, for example, 42 USC \& 601 (1988) (one purpose of AFDC is "to help [ ] parents or relatives to attain or retain capability for [ ] maximum self-support and personal independence . . . ."); Cal Welf and Inst Code $\S 19.1$ (b) (West 1984) (similar provision).

185 See note 199.

${ }^{188} 394$ US at 632 (emphasis added).

${ }^{187}$ See Dandridge $v$ Williams, 397 US 471, 486 (1970).

${ }^{188}$ Craig, 429 US at $199-200$. 
couraging employment seems to fit the bill. Employed persons contribute to a healthy economy, reduce society's welfare burden, and provide an example to others. In view of the billions of dollars spent annually by government on unemployment and welfare benefits, ${ }^{189}$ the importance of encouraging employment ought to be unobjectionable.

\section{B. Establishing a Close Fit, Avoiding Conclusive Presumptions, and Demonstrating a Factual Basis}

The above discussion does not explain why newcomers should be treated differently from long-time residents. In fact, Shapiro declared summarily that "[a] state purpose to encourage employment provides no rational basis for imposing a one-year waitingperiod restriction on new residents only."190 States should encourage the financial independence of individuals in both groups by denying aid to all persons with no plan to seek self-support, regardless of length of residence.

In practice, however, such persons are quite difficult to identify. Few are likely to admit their true intentions. The state must therefore infer undesirable intentions from available circumstantial evidence. However, a state may have no reliable mechanism for determining the intentions of long-time residents. ${ }^{191}$ In the case of newcomers, on the other hand, the very fact that they have moved into the state from a state with lower public assistance levels may reasonably arouse suspicion about their motives. A state might initially presume that (1) the newcomer migrated exclusively to receive higher benefits, and (2) the newcomer would not incur the economic and emotional costs of moving unless he expected to remain on welfare and collect higher benefits for a long time, if not indefinitely. If both these presumptions withstood careful scrutiny, even the Minnesota, Illinois, and California waiting periods, which deny full welfare benefits to all newcomers, might be valid. Giving full benefits to any indigent newcomer would then conflict with the policy of encouraging employment.

189 The federal government spent $\$ 242.2$ billion on education, training, employment, social services and "income security" in fiscal year 1992. Executive Office of the President, Budget of the United States Government: Fiscal Year 1994 at A-6 (GPO, 1993).

100394 US at 637-38.

191 Of course, a welfare waiting period might be stronger constitutionally if some provision were made to deny benefits to long-time residents found to have a mentality of dependency. This would indicate that the state was making a comprehensive effort to battle welfare dependency rather than just picking on indigent newcomers. 
To begin with, however, it is clear that reasons other than higher public assistance levels impel most indigent newcomers to move from one state to another. Several studies have found no statistically significant relationship between AFDC benefit levels and migration rates. ${ }^{122}$ Other studies have found a significant correlation between these variables, but do not assert that higher welfare benefits are the only reason that indigents migrate, or that all migration is induced even in part by benefit levels. ${ }^{193}$ Even if some families do move solely to get more welfare, ${ }^{104}$ the Supreme Court has held it irrational to punish an entire group for the wrongful designs of a few individuals within the group. ${ }^{195}$ To be upheld, therefore, a welfare waiting period must contain a mechanism for eliminating from the burdened group indigents with legitimate reasons for moving.

A statute similar to the original Wisconsin plan would achieve this object admirably. Beyond several specific exemptions, ${ }^{196}$ the Wisconsin waiting period created a general exemption for any person who came to Wisconsin "for a lawful purpose without intent to seek [welfare] benefits . . .."197 Though this statute was silent on the burden of proof in this situation, a newcomer should be able to

192 For a summary of the findings of studies on this subject conducted in the 1970 s, see Gary S. Fields, Place-to-Place Migration: Some New Evidence, 61 Rev Econ \& Statistics 21, 25 (1979).

${ }^{103}$ See id. See also Larry Long, Migration and Residential Mobility in the United States 162-69 (Russell Sage Foundation, 1988); Edward M. Gramlich and Deborah S. Laren, Migration and Income Redistribution Responsibilities, $19 \mathrm{~J}$ Human Resources 489 (1984); Peterson and Rom, Welfare Magnets at 79-83 (cited in note 17).

${ }^{194}$ See, for example, Wisconsin Expenditure Commission, The Migration Impact of Wisconsin's AFDC Benefit Levels: A Report to the Wisconsin Expenditure Commission by the Welfare Magnet Study Committee 60 (1986) ("Migration Impact Report") (reporting that a 1986 telephone survey suggested that thirteen percent of all migrants to Wisconsin within the previous five years who had applied for AFDC were motivated to move, at least in part, by welfare benefit differentials).

${ }_{195}$ United States Dept. of Agriculture v Moreno, 413 US 528, 535-36 (1973) (holding it irrational to deny food stamps to all eligible households containing unrelated persons in order to prevent fraud).

${ }^{106}$ See note 66 . To the specific exemptions provided by the Wisconsin statute would have to be added one allowing unemployable persons to receive full benefits. Given that the purpose of the waiting period is to encourage employment, it would be irrational to apply it to persons who are unable to work. This group would include parents of small children in states that do not compensate parents for day care services.

${ }_{187}$ Wis Stat Ann $\S 49.015$. This exemption was repealed, however, during the 1986-87 legislative session. See Jones, $485 \mathrm{NW} 2 \mathrm{~d}$ at 24.

Although this provision potentially gave more newcomers the benefit of the waiting period exemption, it also created a danger, particularly in cases where a welfare applicant relied solely on his own testimony to prove his legitimate intentions, that a court's decision would reflect the bias against indigent newcomers. As a policy matter, a state legislature acting in good faith could address this danger in several ways, such as by listing any specific 
secure full benefits unless the state can show he had no lawful purpose for entering the state. If the state satisfies this burden, it would be reasonable to presume that the newcomer's only motive for moving was to receive higher benefits. ${ }^{198}$

But there would still be no clear factual nexus between a search for higher benefits and a mentality of dependency. ${ }^{188}$ Thus, the individuals affected (here, indigent newcomers) must have the opportunity to rebut this presumption regarding their mentality for the waiting period to avoid constitutional problems. ${ }^{200}$ For example, indigent newcomers could escape this presumption by producing evidence that their moving costs were particularly low relative to the welfare benefit differential, or that they are serious about finding employment.

\section{Remaining Questions}

The previous two subsections erected the basic structure of a constitutional welfare waiting period. Several issues still merit brief discussion.

1. Can a state deny benefits altogether to new residents with no intent to seek work?

Minnesota and two other states sought to circumvent Shapiro by giving new residents the same level of benefits to which they were entitled in their previous state of residence, rather than cutting off aid entirely. ${ }^{201}$ However, this is not constitutionally required. Its only function is to allow a state to argue that its pur-

exemptions to the waiting period capable of positive proof or by providing for de novo review of an applicant's appeal.

${ }^{198}$ While most indigent newcomers have reasons for moving unrelated to the level of the new state's welfare benefits, a significant number apparently are motivated by that consideration. See Migration Impact Report at 50-60 (cited in note 194).

199 Nor is the connection illogical, however. Moving entails costs. If a person has nothing to draw him to the new state but higher welfare payments, he must intend to collect welfare long enough for the difference in benefits between the new and old states to offset the costs of moving. This may indicate that the person is not serious about job-hunting.

${ }^{200}$ See Mathews $v$ Lucas, 427 US 495, 510-12 (1976). Here, the Court upheld a statute that required illegitimate children to prove dependency in order to receive surviving children's benefits under the Social Security Act while granting a conclusive presumption of dependency to legitimate children. Id at 516. "The statute does not broadly discriminate between legitimates and illegitimates without more, but is carefully tuned to alternative considerations." Id at 513. Similarly, a state enacting the welfare waiting period proposed here can argue that the waiting period is carefully tuned to the likelihood of a mentality of dependency.

${ }^{202}$ See Minn Stat Ann § 256D.065; Cal Welf \& Inst Code § 11450.03; 305 ILCS 5/11-30 (1992). 
pose is not to deter indigent migrants. ${ }^{202}$ An employment-based waiting period permits a state to make that claim even while it denies benefits altogether to new residents with no intent to seek work. In fact, giving benefits to indolent newcomers would give them an unfair advantage over long-time residents, who could be stripped of all benefits if found to be shirking their job-hunting duties.

2. Is there a limit on the permissible length of a welfare waiting period?

Under an employment-based waiting period, a state withholds welfare from a newcomer because his entry into the state raises the presumption that he is averse to the idea of self-support. The question, then, is whether this presumption necessarily fades with the passage of time. After a while, a newcomer will undoubtedly develop ties to his new home. While this may mean that he has found reasons other than higher welfare benefits for living in the state, it is no reason to believe that he has lost his mentality of dependency. On the other hand, the very fact that the person was willing to remain in the state for, say, a year without receiving welfare demonstrates that he must have had other reasons for incurring the costs of moving, and that the initial presumption was wrong. The reason for denying benefits to that person therefore disappears.

How much time must pass before a new resident must be granted benefits? The answer depends on the length of time a person interested only in higher public assistance would be willing to endure hardship during an initial period of residency in order to get higher benefits at the end of that period. An accurate answer would require an individualized determination, with an inquiry into the level of benefits in the new state compared to the old state, the absolute level of benefits in the old state, and other casespecific facts.

3. What are a state's obligations pending a hearing?

Bureaucracy is infamous for delays. Weeks or months may pass after a newcomer establishes residence in a state before the state affords him an opportunity to contest the presumption that he is not entitled to welfare benefits. May the state withhold benefits in the interim? Certainly not. To permit this would essentially

202 See text accompanying note 69 . 
allow the state to transform a rebuttable presumption into a conclusive presumption through dilatory administrative tactics. A much larger group of indigent newcomers would lose benefits than the employment rationale justifies.

\section{ConcLusion}

Under the intermediate form of scrutiny advocated in this Comment, states possess at least a limited ability to adopt welfare waiting periods, provided that they are designed to encourage employment rather than to deter indigent migrants from moving into the state. However, due to the low percentage of newcomers who could actually be denied welfare pursuant to a valid waiting period, a state might realize only minimal savings. Indeed, the costs of granting hearings to newcomers might well outweigh any such savings, making the system financially impractical. This suggests not only that the states' hands might be tied with respect to the "welfare magnet" problem, but also that the problem might have been greatly exaggerated to begin with. 
